Special Section: The economies, ecologies and politics of social forestry in Indonesia Research Article

\title{
Identifying the determining factors of recreation demand in Kongar Lake of South Sumatera: An individual travel cost approach
}

\author{
Suhel $^{1}$, Adul Bashir ${ }^{1, *}$, Saadah Yuliana ${ }^{1}$ \\ 1 Department of Development Economics, Faculty of Economics, Universitas Sriwijaya \\ * Corresponding author: abd.bashir@unsri.ac.id; Tel.: +62852 68599948
}

\begin{abstract}
Assessing the economic value of natural resources is always challenging and depends on various perspectives. Specifically, this study seeks to identify the determining factors of recreation demand regarding the Kongar Lake of South Sumatera. The data was obtained from a survey of 150 individuals who visited the lake. The approach used descriptive statistics and an individual travel cost method (ITCM) to conduct the investigation of distributional effects across variables on the number of visitors by using a linear multiple regression approach with a natural logarithm model. The findings suggest that (i) joint recreation demand is influenced by travel costs, income, distance, education, age, and work hours per day; (ii) in part the results of this study show that determining factors of recreation demand are based on travel cost, distance, and education; (iii) the consumer surplus was IDR.16,912 per visit and the annual recreational value included 1,720 people who visited the lake annually over an area of 5,298,288 per ha. The results of this study reveal that Kongar Lake has a considerable recreational value that, from this point of view, can help policymakers to make the case for preservation planning and sustainable utilization of natural resources.
\end{abstract}

Keywords: Environment; Kongar Lake; recreation; travel cost; willingness to pay

\section{Introduction}

One of the increasingly popular alternatives for encouraging regional economic growth is to develop the tourism sector. Indonesia's tourism growth in recent years has begun to take on greater prominence. Indeed, the current tourism sector in Indonesia occupies the fifth position as a producer of foreign exchange in the world (Tourism Ministry, 2016). In the past, the role of tourism in Indonesia has mainly been measured through foreign exchange earned from the expenditure of inbound tourists. Recently, Indonesia has placed more attention on domestic tourism, which has proved to be a major source of tourism expenditures (Ferland, 2011). The tourism targets in 2019 include 20 million foreign tourist visits, and in the future it is foreseeable that the tourism sector replaces oil and gas as the main source of foreign exchange in Indonesia. Based on data from the Central Bureau of Statistics (BPS), tourism contributions to national GDP increased from around 9\% in 2014 and is targeted to reach 15\% by the end of 2019 (Tourism Ministry, 2016).

Several resource-rich developing countries have begun to make tourism a sector that drives economic growth (Pirikiya et al, 2016). However, the problem in each region is the difficulty of assessing environmental resources that have high economic value. In addition, the tourism sector has a positive impact on employment. In 2015 the availability of new employment reached 11 million workers and is predicted to rise by 13 million in 2019. As for the target of foreign exchange achievement during these years, the Tourism Ministry believes it will reach a GDP from the tourism sector amounting to IDR.280 trillion in 2019. Foreign tourist visitors are projected to reach IDR.144 trillion in 2015 (Tourism Ministry, 2016).

Assessment of the economic value of natural resources provides a tool to measure the value of money from goods and services provided by natural resources through specific valuation techniques (Dixon \& Sherman, 1990; Pirikiya et al., 2016; Suhel \& Bashir, 2018). Goods and services produced from natural and environmental resources include aspects such as economic value, recreational 
value, aesthetic value, and environment value. Those aspects cannot be traded, and thus it is difficult to obtain data on the price and quantity of goods and services, particularly as they relate to the assessment of natural resources (Pirikiya et al., 2016). The value generated from natural resources can be categorized as ordinal use values because the benefits derived from consuming goods cannot be quantified. Therefore, the approach used to assess natural and environmental resources apply indirect measurement techniques using the travel cost method (Hanauer \& Reid, 2017). The travel cost approach is a valuation method for estimating the demand curve of recreational goods, especially related to outdoor recreation (Dixon \& Sherman, 1990; Gössling, 1999; Grafton et al., 2004).

There are several methods developed by experts used to assess the economic benefits generated by a recreation area. Two prominent methods are the individual travel cost method (ITCM) and the zone travel cost method (ZTCM). ITCM estimates are based on survey data from each individual (visitor), not based on zone grouping, while ZTCM estimation based on data relating to the zone of origin of visitors (origin zone grouping). The travel cost method can be used to estimate the cost of benefits from recreational areas such as (i) the elimination of existing recreational areas; (ii) the addition of new recreation areas; and (iii) changes in the quality of the environment at recreational locations. The TCM method is relatively uncontroversial because it is modeled on standard economic methods to measure values, and uses information about actual behaviors rather than verbal responses to hypothetical scenarios. It is also based on the simple assumption that travel costs reflect the value of recreation. In addition, in terms of economic valuation there are two types of assessments, namely (i) the revenue assessment, which is an approach that calculates the revenue from natural resources generated from significant revenues from tourist fees; (ii) the nonrevenue assessment, which conducts an economic valuation by deriving estimates of economic value from natural resources, whether in the context of market prices or in imperfect markets (Dixon \& Sherman, 1990; Sohngen, Lichtkoppler, \& Bielen, 1999).

One of the benefits of a conservation lake area is that it is relatively concrete, such as the bounded opportunities to assess benefits of water flow protection. However, other benefits such as the value of its very existence still looks abstract. It should be underlined that this aspect causes difficulty in calculating the economic value of the conservation area because they are dispersed across five characteristics, namely: (i) there is no competition in consuming services provided by the conservation area; (ii) there are no exceptions which are open access to natural resources and the environment, which often leads to the absence of market prices on these natural resources even though the actual value is quite large; (iii) the benefits of flowing out of the region such as the benefits of a conservation area may spread to non-local residential areas, such as provinces or other countries, which cause the prices of these services to be below their true value; (iv) uncertainties such as market failure that occur due to incomplete or incorrect information about the scarcity of natural resources and the environment within the conservation area; (v) cannot be renewed, for example if a conservation area is damaged, it will take a long time to restore it to a state that can achieve the same value so that the supply of goods and services becomes so inelastic that the actual value of the conservation area is difficult to measure (Dixon \& Sherman, 1990; Grafton et al., 2004).

The concept of economic valuation can be conducted as an assessment using the cost approach. This assessment approach calculates the opportunity cost of the conservation area, and among others, evaluates the (i) costs or losses suffered by the community due to loss of access to the utilization of resources and the environment within the conservation area; and (ii) costs incurred to maintain the value of goods and services from natural conservation areas (Grafton et al., 2004). In addition, costs can arise such as (i) opportunity costs, the economic value of conservation areas can be known through the present net value of various land use alternatives; (ii) prevention costs, which may prevent community losses; (iii) replacement cost, the conservation area serves to maintain the quality of land and nutrient cycles. If deforestation occurs for example, it will increase soil erosion and loss of fertile soil layers containing many nutrients. For example, nutrients can be 
replaced by fertilizers (Premono \& Kunarso, 2010; Rachmansyah \& Maryono, 2004). The costs incurred for the purchase of fertilizer reflect the economic value of the conservation area.

Natural and environmental resources have a direct use value that can be calculated using traditional calculation methods, such as (i) indirect utilities; (ii) future value; and (iii) nonconsumption utilities (Pearce \& Turner, 1991; Tietenberg \& Lewis, 2012). In the case of conservation areas, direct use values include food produced in the form of marine or forest products and recreational benefits. These benefits are easy to quantify as benefits derived from conservation areas, for example, admission from the forest products, and non-forest products harvested, and the cost of lost opportunities, such as the loss of rights to mining resources, which in economics are often referred to as opportunity costs. This market mechanism does not reflect the nonconsumption utility. However, the indirect utility is evident in that there is a clear link between conservation areas and regional and local economic development. Therefore selected utilities in this paper include the benefits of natural resources and the environment.

Generally, these unknown products have no current market value. Non-consumptive utilities include inheritable existence value. The existence value is the value given by communities for the spiritual, aesthetic and cultural benefits from the conservation area (Farrow et al., 2000; Pearce \& Turner, 1991; T. Tietenberg \& Lewis, 2012). The value that can be inherited is the value given by the current community today to a particular region in order to remain intact to be given for the future generations. These values are also not taken into account in market prices.

The utility of a conservation area pushes the marginal utility directly through a multiplier effect process (Grafton et al., 2004). For example, the money incurred from a tourist for a hotel will increase expenditures in an area, as local food providers and farmers will cooperate in the supply of food for the hotel business. However, the hotel business also will increase the cost of spending, such as increased wastewater production, which in turn can substantially reduce net profits. Therefore, the need to look at the economic benefits must also proceed with the requisite evaluation of costs of a conservation area.

The potential of nature tourism will have positive and negative impacts, both in economic, social, environmental and community terms (Zaei \& Zaei, 2013). As an example, positive impacts in tourism development can be in the form of increased public incomes, increasing the country's foreign exchange, availability of jobs, and the availability of new business potential for the community, which also helps to raise awareness of the community to preserve the environment. Meanwhile, the negative impacts from tourism development arise in the form of the destruction of these attractions, both of buildings and environment (Pirikiya et al., 2016; Zaei \& Zaei, 2013).

According to data in 2015, there are several provinces in Indonesia popular among tourists. Regions most frequently visited by tourists are led by Bali with approximately more than 3.7 million foreign tourists, followed by Jakarta, Yogyakarta, East Java, West Java, North Sumatera, Lampung, South Sulawesi, South Sumatera, Banten, and West Sumatera (Suhel \& Bashir, 2018). South Sumatera also has some interesting places or attractions and includes popular tours in Indonesia. This area has a relatively complete set of natural settings that make it an ideal tourist destination, including mountains, beautiful landscapes of rolling hills, lakes, large riverine and coastal areas. There are various efforts that are taken across this region to protect beautiful scenery, even though it has not been well managed for the advancement of the tourism sector. Economic benefits from natural tourist areas in South Sumatera are less known because of some of the immeasurable aspects. Assessment of natural tourism is important to support various strategies and considerations in development and sustainable management (Díaz \& Espino-Rodríguez, 2016; Martín et al., 2017).

The annual trends of local and international tourists that travel to South Sumatera are listed in Figure 1. Based on Figure 1, both foreign and domestic tourists show a positive trend, in which the average growth of the number of foreign tourists in the period of $2000-2016$ is $10.61 \%$, while for domestic tourists growth occurred by $31.46 \%$. Based on published data in 2017 by the Ministry of 
Tourism, the main objectives of tourism visits include recreation, business, sports, arts, and seminars and congresses. The number of tourists, and the variety in type of visits means that tourism promotion by various communities and among local governments is quite vigorous, indicating strategic possibilities of areas of South Sumatera to attract for foreign and domestic tourists.

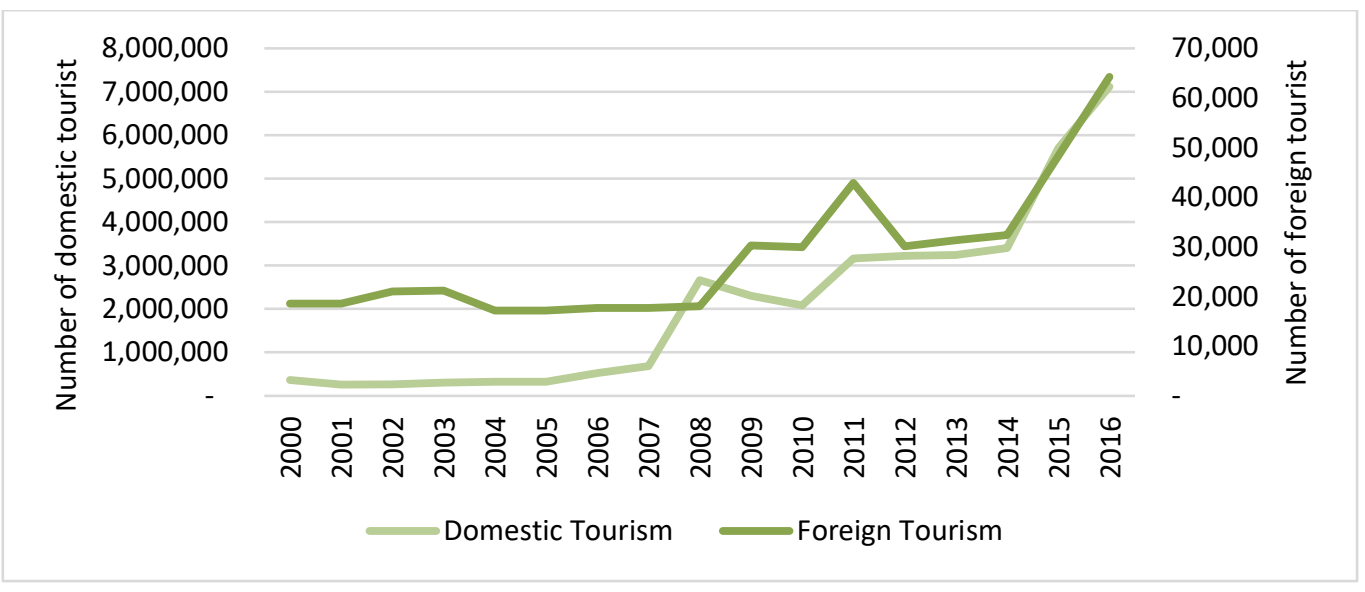

Figure 1. Number of domestic and foreign tourists in South Sumatera, 2000-2016 Source: BPS, South Sumatera in Figures 2017 (processed)

The number of tourist arrivals provides benefits to both the government and private sector related directly or indirectly to tourism. Accommodation establishments and tourism services such as hotels, restaurants, travel agencies and travel, recreation, amusement parks, and business for general industries, as well as historic sites of South Sumatera will benefit from tourism visits. Therefore, overall, increasing the number of tourists coming to South Sumatera will add jobs to the community and improve the economy of South Sumatera (Suhel \& Bashir, 2018).

Kongar Lake is one potential site for development as a tourism destination in a rural area of South Sumatra. The reason for choosing this location is because the lake has a recognized beautiful scenery located on the East of Palembang City, and the lake covers a manageable size of 14 hectares (ha). However, as a tourism site, the site is not yet supported by comprehensive data. The lake is included in the category of public goods that has three types of value, namely: (i) the value of benefits; (ii) the value of choice; and (iii) the value of existence (Milon, 1988; Salem \& Mercer, 2012). In addition, the lake fits the strategic criterion as a natural tourism area, among others: (i) has a natural attraction in the form of plants, animals or ecosystems, and beautiful scenery; (ii) has an area that is sufficiently large to ensure the preservation of potential functions and appeal to tourists for natural recreation; (iii) the surrounding environment supports the development of natural tourism (Irshad, 2010).

Based on the above review, a more appropriate approach to measuring economic value indirectly on this lake recreation site is the individual travel cost method (ITCM) approach. By knowing the travel cost of each individual, then the economic value can be estimated through the individual travel cost given to environmental resources. In addition, the ITCM method has been widely proposed as a common approach to evaluating recreational sites in several studies, such as studies conducted by Clough (2013); Fleming \& Cook (2008); Limaei, Ghesmati, Rashidi, \& Yamini (2014); Pirikiya et al. (2016); Shrestha, Stein, \& Clark (2007); Sohrabi Saraj et al. (2009); and Twerefou \& Ababio (2012). These studies highlight that the TCM approach is more precise for its application in developing countries. Furthermore, the studies show that TCM is the best method to analyze the demand for recreation and evaluate and determine the willingness to pay (WTP) from recreation areas.

The difference between this study and previous studies is that it is located in the selection of a 
newly developed location. This lake also has an attraction for domestic tourists because of its beautiful scenery and the water in the lake is never dry and remains very clear. It is predicted that this lake will make a large contribution to the local economy. Therefore, this study aims to analyze tourism characteristics in particular, including the factors that affect recreational demand, as well as calculating the economic value of the lake with individual travel cost approach (ITCM). The contribution of this study supports various considerations for government planning in the management of the Kongar Lake conservation area in the future.

\section{Materials and Methods}

\subsection{Data and sources}

Data collection includes primary and secondary data. Primary data collection was conducting by using an incidental sampling technique. The determination of sample size applied the Slovin formula (Bartlett et al., 2001) with precision consideration of $10 \%$, and the minimum sample is 99 respondents. The number of samples used in this study included 150 respondents in 2017.

\subsection{Travel cost method approach}

The travel cost method is a non-market procedure which seeks to place a value on a recreational object by using consumption behavior in related markets (Fleming \& Cook, 2008; Pirikiya et al., 2016). The underlying assumption in TCM approaches is that the place value is equal to the costs respondents pay to use that place. In essence, the TCM valuation approach examines the recreational use benefit for a specific recreation object by relating demand to the particular object (the number of object visits) to its price (as visit costs). A simple TCM model can be defined by a trip generation function (f) as follows (equation 1 ):

$$
\begin{gathered}
N v=f(C, Z) \\
N_{i}=\alpha_{0} C_{i}^{\alpha_{1}} Z_{i}^{\alpha_{n}} \mu^{u}
\end{gathered}
$$

Where: Nv is number of visits to a recreation object; $\mathrm{C}$ is cost per visit; and $\mathrm{Z}$ is other socioeconomic variables which significantly explain $\mathrm{Nv}$; notation $\alpha_{0}, \alpha_{n}$ is the coefficient in the model, and notation $\mu$ is the error term.

There are two forms of Individual travel cost method (ITCM) and Zone travel cost method (ZTCM). The method used in this study to analyze the demand for outdoor recreation. Generally, ITCM estimates are based on survey data from each individual (visitor), not based on zone grouping, while ZTCM estimation based on data relating to the zone of origin of visitors (origin zone grouping). Based on the results of the process and inventory of survey data that has been carried out, the approach used in this study is the ITCM approach.

According to previous studies, these models are linear from the point of view of their parameters. However, from the point of view of input variables, it can also be linear or non-linear. This study investigates the effects of explanatory variables including economic and social variables on the number of visits to estimate the recreational value from a conservation area lake, and thus the linear model is used as follows:

$$
\mathrm{Nv}_{\mathrm{i}}=\mathrm{f}\left[\left(\mathrm{Tc}_{\mathrm{i}}+\mathrm{P}\right), \operatorname{Inc}_{\mathrm{i}}, \operatorname{Dist}_{\mathrm{i}}, \mathrm{Edu}_{\mathrm{i}}, \mathrm{Age}_{\mathrm{i}}, \mathrm{Wh}_{\mathrm{i}}\right]
$$

Equation (3) above can also be presented in the form of the econometric model equation in equation (4), which are transformed into natural logarithms, and therefore the model is presented in the equation (4) as follows: 


$$
\operatorname{lnNv}_{i}=\beta_{0}+\beta_{1} \operatorname{lnTc}_{i}+\beta_{2} \operatorname{lnInc}_{i}+\beta_{3} \operatorname{lnDist}_{i}+\beta_{4} \operatorname{lnEdu}_{i}+\beta_{5} \operatorname{lnAge}_{i}+\beta_{6} \operatorname{lnWh}_{i}+\mu_{i}
$$

In this case the explanation of the above model is $\mathrm{Nv}$ which is the number of visits; $\beta_{0}$ is an intercept; $\beta_{1}$ until $\beta_{6}$ are the parameters of the coefficient in the model; Tc is the cost of travel; Inc is monthly income; Dist is the distance of the inhabitants of the district of origin of the visitor Edu is the level of education; Ag is the age of individual, and $\mathrm{Wt}$ is the working time.

The variables choice in the model is based on demand theory, which is demand is accompanied by the willingness and ability to pay for goods and services. The demand for goods and services is highly determined by the price of goods or services and individual income, but in this study, we consider social variables because the type of demand is a service, which can also be influenced by individual education and individual age. In addition, we also consider opportunities which are indicated by the distance variable and working hours.

In this way, the base of ITCM is formed. After estimating the above formula by gathered data, it is used to estimate the request equation. By increasing the hypothetical participating price and by equation (4), the number of total visits ( $\mathrm{Nv}$ ) for each variable prices is obtained as follows:

$$
\mathrm{Nv}_{\mathrm{i}}=\sum_{\mathrm{i}=1}^{\mathrm{n}} \mathrm{f}\left(\mathrm{Tc}_{\mathrm{i}},+\mathrm{P}\right)
$$

The important and basic result taken from estimating ITCM is to estimate consumer surplus (CS). The consumer surplus is obtained from the total individual CS. The level below the Marshal cycloid will be the reagent of the consumer surplus (Cs). The lake has no participating cost, the whole level below the cycloid will show consumer's economic benefit (Ortacesme, Özkan, \& Karaguzel, 2002; Twerefou \& Ababio, 2012) in equation (6) as follows:

$$
\mathrm{Cs}=\frac{\mathrm{Av}}{-\left(\beta_{1}\right)}
$$

Where: $C s$ is consumer surplus; $\beta_{1}$ is the coefficient value of travel cost; $A v$ is the visits average of respondents per year in the lake.

$$
\mathrm{TEV}_{\mathrm{i}}=\mathrm{Cs}_{\mathrm{i}} \times \mathrm{Av}_{\mathrm{i}} \times \mathrm{Tv}_{\mathrm{i}}
$$

Where: TEV is total of economic value per year; Av is average of economic value; Tv is the number of visitors in the district per year; and $C s$ is individual consumer surplus per year.

\section{Results and Discussion}

\subsection{Socio-economic characteristics}

Based on results of the study, Figure 2 below shows that the number of visits conducted by an individual in a year is used as a dependent variable in the model. The rate of visits to the Lake included only one visit a year (61.3\%). The next was followed by twice a year (12.7\%) and three visits $(11.3 \%)$, and then more than five visits (7.30\%). So the average number of visits in one year is 2.55 . 


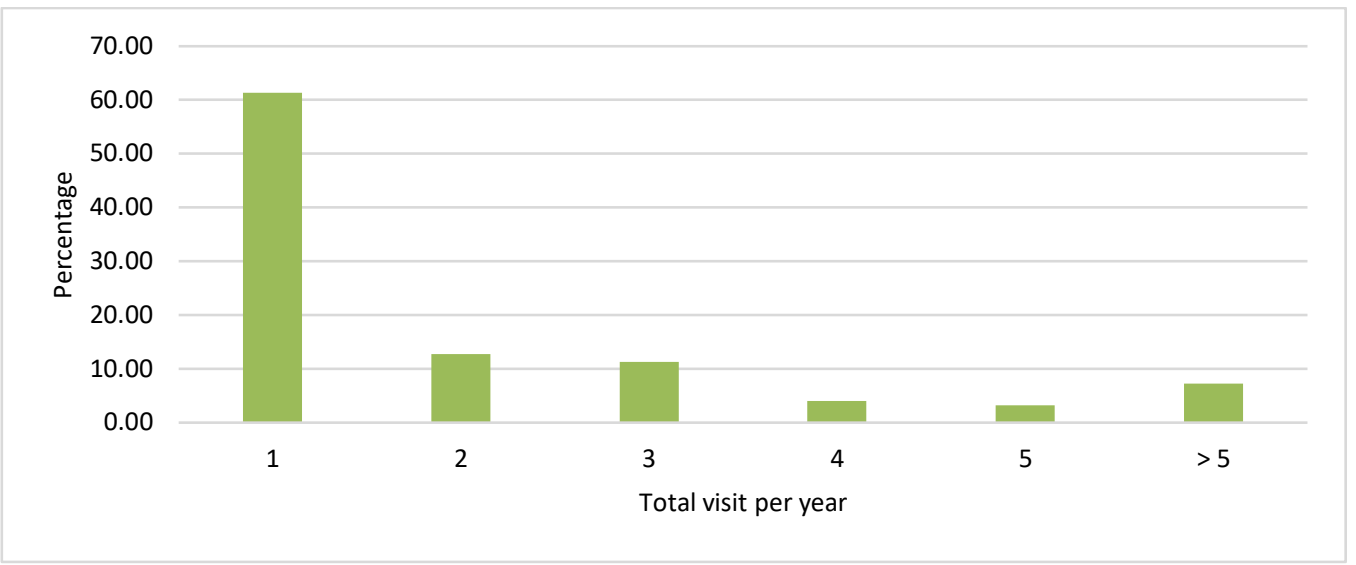

Figure 2. Distribution of respondent visits Source: Field research (processed)

Figure 3 shows that the age distribution of the sample varies considerably. However, dominant visitor ages range from $25-29$ years or $29.33 \%$ of the total sample who visited the Lake. While visitors who have age ranges of 56-60 years was very little, or 3.3\%. It shows that the area is generally in demand by productive age categories, and frequently consist of younger visitors such as students.

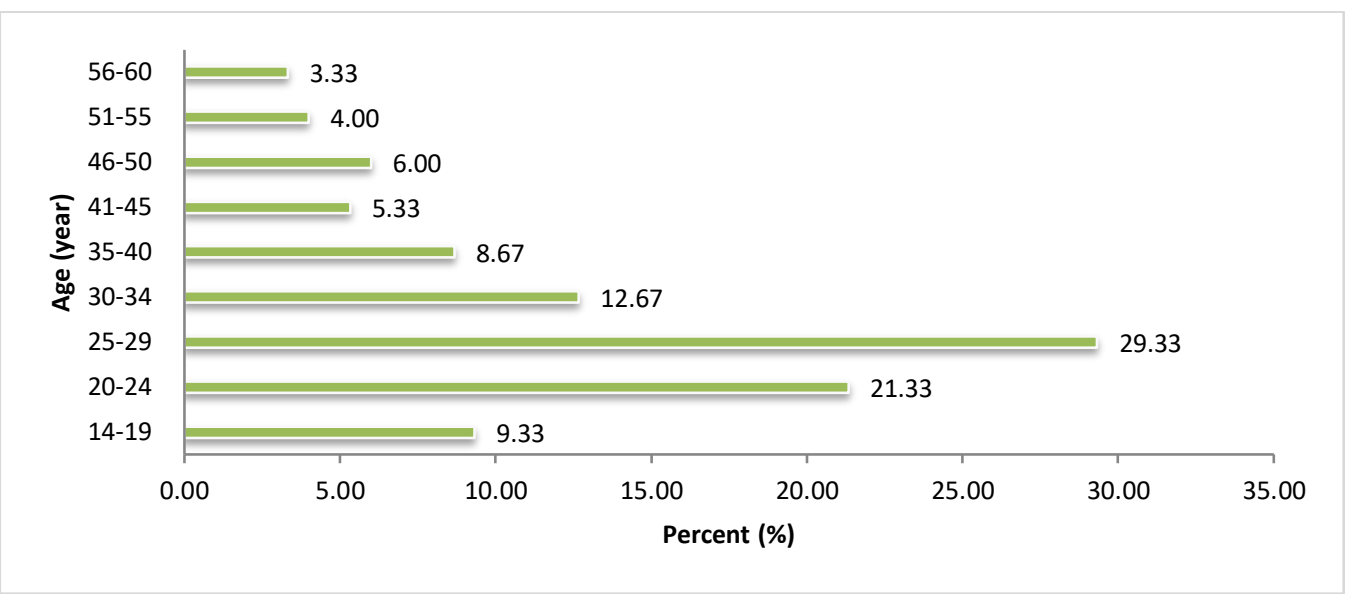

Figure 3. Distribution of respondent age

Source: Field research (processed)

In addition, visitor distribution by gender can be seen in Figure 4 presented below. Male visitors made up as many as 89 people or $59 \%$ of the total sample, while female visitors consisted of 61 people, or $41 \%$. The data indicates that tourists who visit the lake are mostly male.
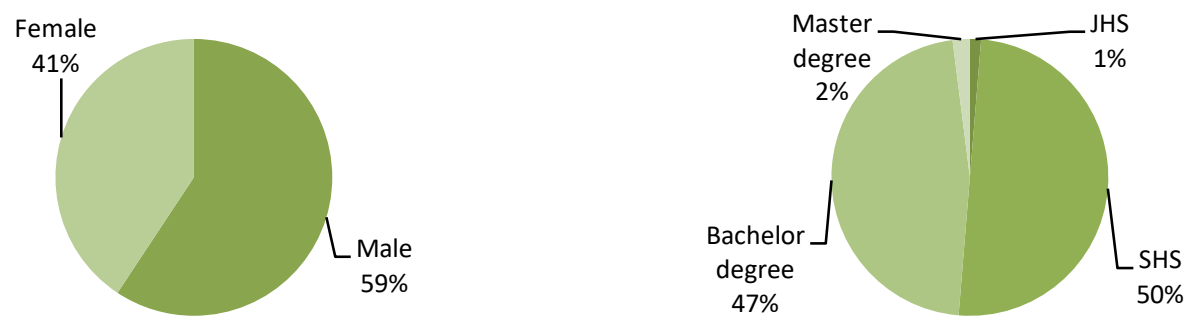

Figure 4. Distribution of Gender and education of respondent's

Source: Field research (processed) 
Figure 4 also shows the distribution of visitors by education, the tourists who visit the Lake are quite varied. But most visitors have a senior high school level of education at $50 \%$. While other visitors have bachelor degree at $47 \%$, master degree at $2 \%$, and junior high school education at $1 \%$. This shows that the site is quite attractive to younger visitors.

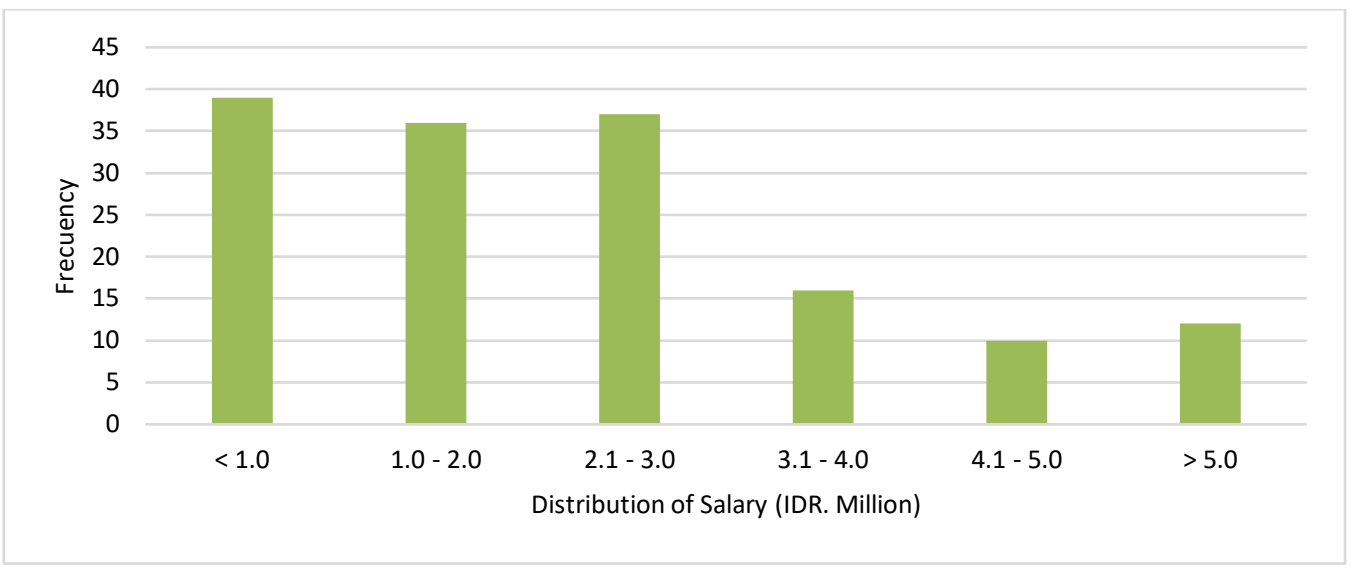

Figure 5. Distribution of income (IDR million)

Source: Field research (processed)

Figure 5 show that the income distribution of visitors vary considerably. Based on the data collected by the survey, it shows that most income falls into the category of less than IDR.1.0 million, which is $26 \%$ of the total sample (most sample student's); others with income ranging from IDR.1.0 - 2.0 million and IDR.2.1-3.0 million, which is $24 \%$ of the total sample; other income categories ranged from IDR.3.0-4.0 million as much as $11 \%$ of the total sample, and other respondents whose incomes ranged from IDR.4.1 - 5.0 million, which is 7\%; and other has the income of more than IDR.5.0 million, which is $8 \%$ of the total sample. The lowest income is IDR.200 thousand, and the highest is IDR.29 million, with an average income of IDR.2.7 million. This indicates that individual needs for vacation, leisure and recreation with family are important, and may not require high costs.

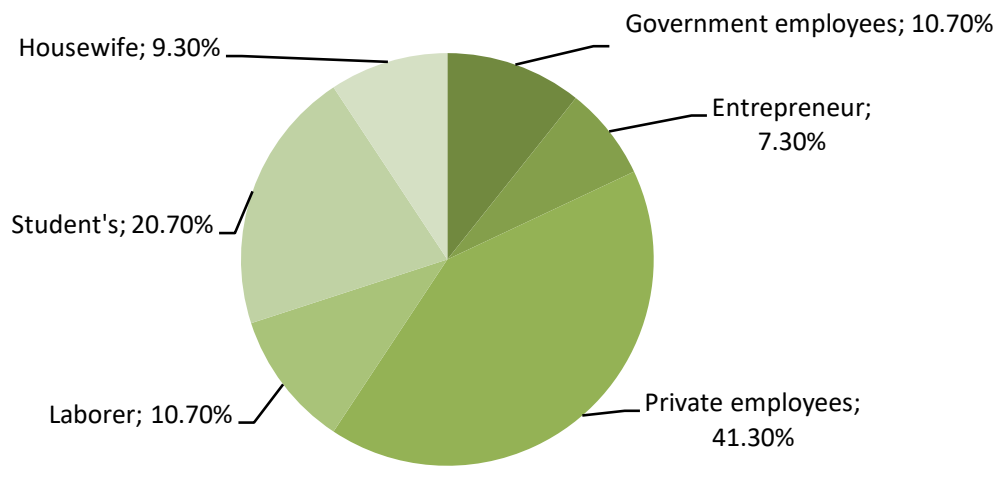

Figure 6. Distribution of respondent's occupational

Source: Field research (processed)

The survey results show that the distribution of respondent employment varies. The type of occupations were dominated by private employee at $41.3 \%$, followed by students at $20.7 \%$. There were also respondents who work as civil servants and laborers with the same distribution of $10.7 \%$ (Figure 6). 


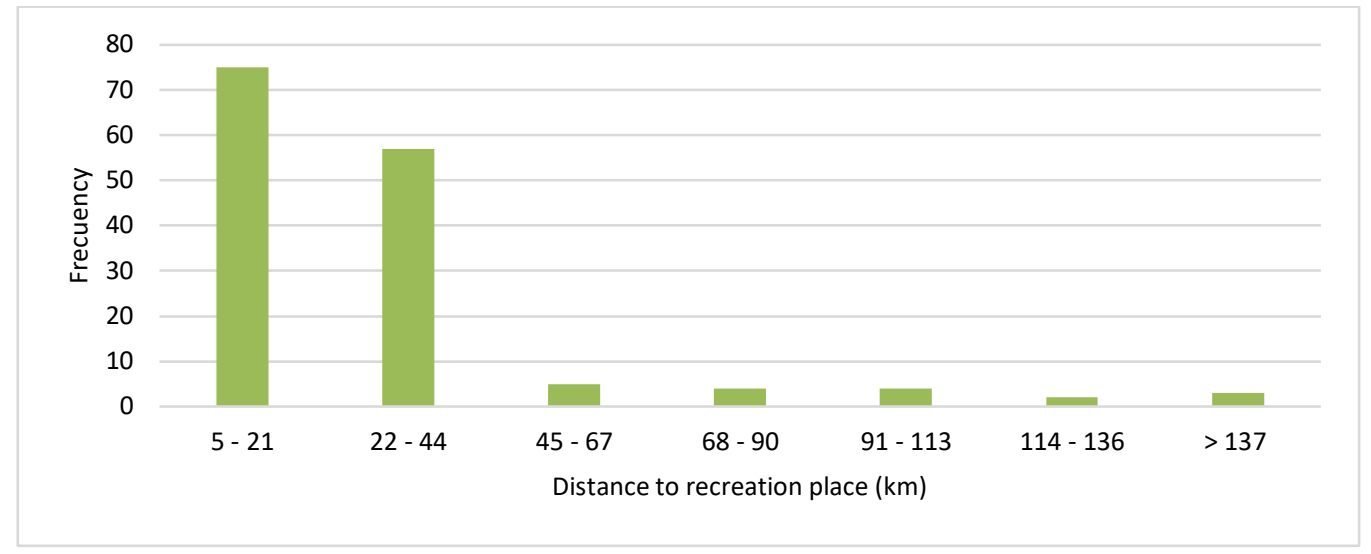

Figure 7. Distribution of distance to recreation place Source: Field research (processed)

Figure 7 above shows that the visitor's distance to the lake also varies. In the data, most visitors live at a distance to the site between $5-21 \mathrm{~km}$, with a distribution of $50 \%$ of the total sample, and then further distances between $22-44 \mathrm{~km}$ or $38 \%$ of the total sample. As for the distances exceeding $114 \mathrm{~km}$ amounted to $3.3 \%$ of the total sample distribution. This means that in general, the lake is more visited by local tourists.

Another sample characteristic is working hours (Figure 7). The data obtained indicates that most visitors have working hours of 8 hours per day consisting of a distribution of $43.33 \%$, followed by respondents who work for 6 hours per day with a distribution of $16 \%$. The lowest working hours are for 3 hours per day with a distribution of $2 \%$. For this case, because the demand type is service, so we also consider the opportunity to make the request is a working hour variable, so working hours is an important factor that determines recreation demand, this has also been stated by Pirikiya et al. (2016).

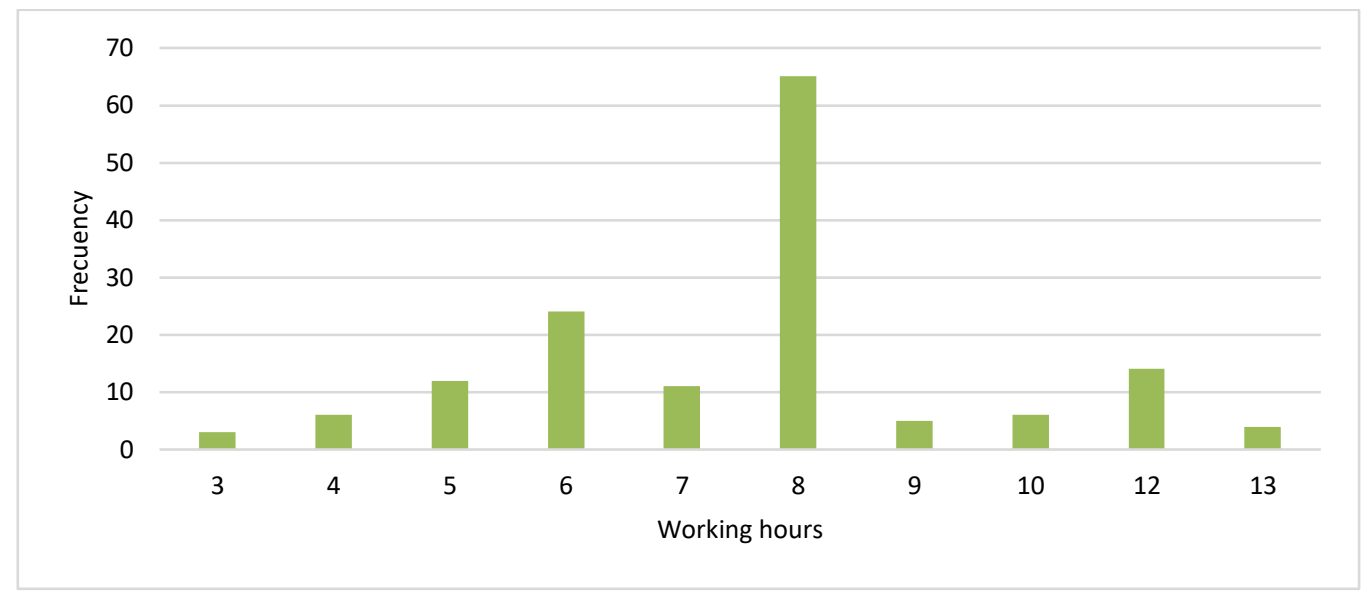

Figure 8. Distribution of working hours by respondent Source: Field research (processed)

Meanwhile, responses to the environmental conditions of the lake varies considerably. The responses indicate that the majority of respondents stated that the lake has beautiful natural panoramic views with a distribution of $38 \%$ of the total sample, while other respondents stated that the lake has sufficient natural beauty with a distribution of $31 \%$, and respondents who stated lake has natural beauty with a distribution of $24.7 \%$ (Figure 9 ). This is a major consideration for tourists 
to visit this lake.
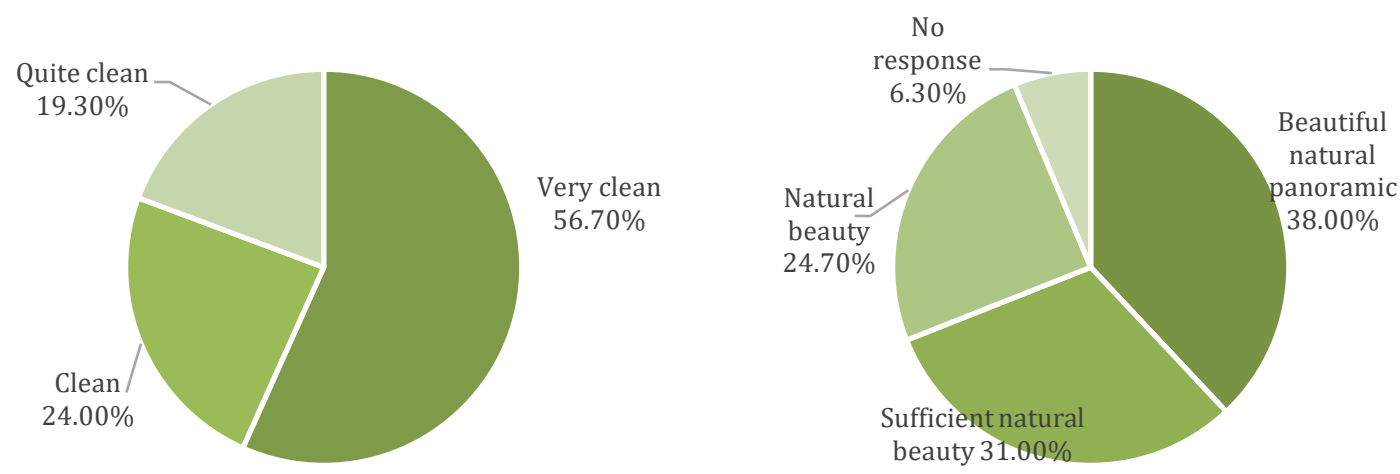

Figure 9. Distribution of respondent's perception of scenery and cleanliness Source: Field research (processed)

Based on direct observation the beauty of the lake is still well maintained, and this is one reason for tourists to visit the lake. The survey results also show that most of the respondents stated that the lake is very clean, with the distribution percentage of $56.7 \%$ of the total sample, and the respondents stated this lake is quite clean which is by $24 \%$. Cleanliness of a tourist attraction is one of the more important factors determining continued recreation demand (Figure 9).

The lake should be protected from pollution and wastewater to ensure the sustainability of existing ecosystems. Environmental sustainability is important because the environment has a high economic value. Therefore, environmental sustainability will be a shared responsibility, as environmental degradation will have a negative impact on future sustainable development.

\subsection{The model estimation}

In the diagnostic test of multiple regression equation model in Table 1 , shows the results of autocorrelation test based on Jarque-Bera criteria, and indicates that the probability of Jarque-Bera $(J B)>0,05$. Therefore it can be concluded that the residual is normally distributed (Table 1 ). In addition, heteroscedasticity test with Breusch-Pagan criteria showed the probability of $X^{2}>0.05$. Therefore it can be concluded that there are no symptoms of heteroscedasticity in the model.

Table 1. Result of model diagnostic tests

\begin{tabular}{llcc}
\hline Diagnostic & Criteria & Prob. & Note \\
\hline Normality & Jarque-Bera & $0.0801>0.05$ & Reject $\mathrm{H}_{\circ}$ \\
Heteroscedasticity & Breusch-Pagan & $0.3352>0,05$ & Accept $\mathrm{H}_{\circ}$ \\
\hline
\end{tabular}

Source: Author's calculation

Table 2 presents the results of correlation tests between independent variables indicating that all coefficient values are still within the tolerance limit that is below 0.80 , which is also stated by Gujarati (2004), meaning that the relationship between independent variables are not strong enough. The correlation coefficients between these variables are still below the value of 0.80 , so it can be concluded that there is no symptom of multicollinearity in the model. 
Table 2. Examination of correlation matrix of the model

\begin{tabular}{llrrrrr}
\hline Variable & InTC & \multicolumn{1}{l}{ InINC } & InDIST & InEDU & InAG & InWH \\
\hline InTC & 1.000 .000 & - & - & - & - & - \\
InINC & 0.000890 & 1.000 .000 & - & - & - & - \\
InDIST & 0.196905 & -0.019649 & 1.000 .000 & - & - & - \\
InEDU & -0.029317 & 0.146947 & 0.036933 & 1.000 .000 & - & - \\
InAG & 0.009847 & 0.539371 & -0.000269 & -0.087578 & 1.000 .000 & - \\
InWH & 0.070848 & 0.122762 & 0.079071 & -0.325089 & 0.247145 & 1.000 .000 \\
\hline
\end{tabular}

Source: Author's calculation

In Table 3, we present the model estimation using OLS estimator. The result of this estimation shows that jointly (F-stat), from across six variables in the regression model, the variables including travel cost, income, distance, education, age, and working hours were statistically significant and their signs were similar to economic theories. In short, they had effects on recreation demand in the Kongar lake.

Based on the findings, travel cost affects recreation demand significantly at a $5 \%$ level, the sign of the coefficient shown is negative, with coefficient value at -0.150776 . This means that if travel costs increase by 100,000 , it will decrease recreation demand by $0.15 \%$. The higher travel costs will be the main consideration for tourists, the higher the cost it will further reduce the individual's desire for traveling, as also stated by Pirikiya et al. (2016); and Sohrabi Saraj et al. (2009). One variable also has a sign of a negative coefficient and the significant effect of this is the distance variable, and with a coefficient value of -0.832026 , means that if distance increased by one kilometer, it would decrease recreation demand by $0.83 \%$ with the assumption of ceteris paribus, meaning that the further distance traveled to the lake, the demand for recreation will decrease. Because the mileage will be considered by individuals to travel, the farther distance than will reduce individual interest in traveling, as also stated by by Pirikiya et al. (2016). The result of the model estimation using multiple regressions with ordinary least square (OLS) is presented in Table 3 as follow:

Table 3. Result of model estimation

\begin{tabular}{llr}
\hline Variable & Descriptions & Coefficient \\
\hline C & (constant) & $11.23761^{* * *}$ \\
InTC & (travel cost) & $(1.906903)$ \\
& & $-0.150776^{* *}$ \\
InINC & (monthly income) & $(0.073181)$ \\
& & 0.050781 \\
InDIST & (distance) & $(0.096738)$ \\
& & $-0.832026^{* * *}$ \\
InEDU & (education level) & $(0.110634)$ \\
& & $0.914263^{* *}$ \\
InAGE & (age) & $(0.389532)$ \\
& & 0.096055 \\
InWH & (working hours) & $(0.259082)$ \\
R-squared & & 0.135947 \\
Adj R-squared & & $(0.264716)$ \\
Log likelihood & & 0.322673 \\
F-stat & & 0.294254 \\
Prob(F-stat) & & -184.3721 \\
Sorces:Autorscalcus & 11.35401 \\
& & 0.000000 \\
\hline
\end{tabular}

Sources: Author's calculation

Note: ${ }^{*}$ indicates significant at $10 \%,{ }^{* *}$ significant at $5 \%$, and ${ }^{* * *}$ at $1 \%$ 
In addition, the education variable has a positive coefficient, which was significant at the $5 \%$ level. This coefficient indicates that increasing the education level by one year can make an increase of recreation demand by $0.91 \%$. The education level will determine the choice of individual needs for goods and services, the higher of individual education level, then the greater the choice of consumption. In this case, individuals who have higher education will make choices in achieving maximum utility. This has also been observed and documented by Nillesen, Wesseler, \& Cook (2005); Ortacesme, Özkan, \& Karaguzel (2002); and Pirikiya et al. (2016). On the other hand, the income variable does not have a significant effect on recreation demand. These results indicate that income does not affect individuals interested in engaging in recreation activities. In addition, it seems as though recreation has also become a need of every individual so that income does not act as the main factor in determining the individual who wants to participate in recreation.

Another variable that does not have a significant effect on recreation demand is age and the working hour variable. The results indicate that the age variable and working hours are not the main factor for an individual in determining the desire to conduct recreation. Statistically, the value of the determination coefficient (R2) in the model is 0.322673 . These results indicate that the dependent variable can be explained by the independent variable at $32.3 \%$, and $67.7 \%$ is explained by other variables outside of the model such as family member, gender, and others. Subsequently, the value of F-statistic was significant at a $1 \%$ level, which shows that all independent variables in the model has a significant effect on recreation demand at the $1 \%$ level. The estimated equation of travel cost according to the finding of the research in Table 3 is inserted in equation 8, as follow:

$$
\begin{gathered}
\mathrm{Nv}=11.2376-0.15078 \mathrm{Tc} \\
\mathrm{Tc}=\frac{11.2376}{0.15078}=74.532
\end{gathered}
$$

where: $\mathrm{Nv}$ is the number of people who visit the recreational area; and TC is travel cost.

In this study, the following formula was used to estimate the consumer surplus for individual (equation 6) as follow:

$$
\mathrm{Cs}=\frac{\mathrm{Av}}{-\left(\beta_{1}\right)}=\frac{2.55}{-(-0.150776)}=16.912
$$

After the values were put into the formula, then we were able to obtain the willingness to pay of an individual, the sacrificed value, and the consumer surplus value, which is conducted by integrating the results of the inverse equation with the lower limit at the time of the number of visits, which is null and the upper-limit of the number of visits is average. Based on this estimation, the average willingness to pay is IDR.74,532, while the sacrificed value is IDR.57,621, and the consumer surplus amounts to IDR.16,912. Furthermore, the estimation total of the economic value in Table 4 is expressed as follows:

Table 4. The estimation of annual recreational economic value of the Lake

\begin{tabular}{lcccc}
\hline Economic Value & $\begin{array}{c}\text { Individual Cost } \\
\text { (IDR) }\end{array}$ & $\begin{array}{c}\text { Average visitor } \\
\text { per year } \\
\text { (person) }\end{array}$ & $\begin{array}{c}\text { Average of } \\
\text { Total Visitors } \\
\text { per year }\end{array}$ & $\begin{array}{c}\text { Total of Value } \\
\text { per year (IDR) }\end{array}$ \\
\hline Willingness to Pay (WTP) & 74,533 & 2.55 & 1.720 & $326,901,738$ \\
Sacrificed value (SV) & 57,621 & 2.55 & 1.720 & $252,725,706$ \\
Consumer Surplus (CS) & 16,912 & 2.55 & 1.720 & $74,176,032$ \\
\hline Sources: Author's calculation & & & &
\end{tabular}


Based on these estimations, we show that the Lake covers 14 ha and also has a value at IDR. $5,298,288$ per ha. The cost can be determined as the most effective factor in recreation demand. The relationship between the number of visits and travel cost has a significant and negative correlation, which indicates that with increasing travel cost, then the number of visits will decrease. Table 4 shows the economic value obtained from the estimation result of the model, where travel costs average at IDR.74,523, while the consumer surplus is smaller than the sacrificed value. At the moment, the travel cost average estimated of the number of visitors is based on an expectation of reaching 1,720 people per year. Furthermore, if the assumption of the economic value total per year divided by the number of visitors predictions (1,720 people), obtained an average value of willingness to pay of IDR 190,059 per visit, with a sacrificed value at IDR.146.933 per visit, and consumer surplus at IDR.43.126 per visit. The consumer surplus is the payment difference between the satisfaction obtained by a person to consume a number of items with payment to obtain those goods. This occurs in the area with a unique characteristic (Klempener, 1996). In the area of natural tourism with a unique charm, when travel costs rise, the number of visitors are not drastically reduced, because there is another attraction as a substitution. According to Klempener (1996) the number of visitors will decrease when there is damage or loss of environmental quality.

The implication of this study shows that there is economic value of the above-mentioned recreational site by using the individual travel cost method (ITCM) for estimating the economic values of environmental goods and services. In general, this method is applied to estimate economic values of a place such as national parks, lakes, or conservation and forest parks for recreation. The findings of this study were not consistent to those obtained by Chae, Wattage, \& Pascoe (2012) and Pirikiya et al. (2016), which is estimated to have differences in social-economic characteristics, and sample size. A strong correlation also was found between the number of visits and the income level, when such results were shown in findings by Shrestha \& Loomis (2003); Chae et al. (2012); and Twerefou \& Ababio (2012). Travel cost and income are not the main factors for attracting people to come to the lake. The results showed that local people covered a large number of visitors and that the likelihood of visitations are likely to decrease if greater distances.

\section{Conclusions}

The conclusion of this study shows that taken together, all independent variables had a significant effect on recreation demand, which reflects variables of travel costs, distance, and education level, and which overall has a significant role in attracting visitors to Kongar Lake. Meanwhile income, age, and working hours as variables had no significant effect on recreation demand. Travel cost has a negative relationship and significant effect on recreation demand, but did not have a major effect on recreational demand. The distance then becomes the main factor affecting recreation demand because the farther the distance a tourist has to travel, the likelihood of a visit will decrease. Furthermore, education level has a positive relationship and significant effect on recreation demand. The individual with a high level of education is usually more likely to seek out tourism among beautiful natural resources and protected environments.

The results of this study can improve the quality of environmental services of the Kongar Lake and expand varieties of services that they could supply based on the people's demand. The results of the present study showed that improving the eco-environmental resources and/or ecotourism services can have a valuable effect on the increase of visitor demand and the WTP of a site like Kongar lake, though there are other factors like costs, user characteristics, distance to access the lake, time needed to reach the lake, amount of working hours per week, visitor employment background, the population residing in the park's region, available installations and facilities, and the beauty of natural tourism. All these factors play an important role in maintaining and increasing demand.

Nevertheless, the more important factor is the improvement of eco-environmental resources/ 
services, which can serve as the most significant factor in the effectiveness of attracting the attention of individuals to visit the lake, followed by cost and distance considerations. Accessibility of enough public transportation facilities (e.g., local transportation, hotel or residential venues offering required facilities) could be one way that this study highlights opportunities improve the likelihood of increasing visitors to visit the area.

\section{References}

Bartlett, J., Kotrlik, I. J. W., \& Higgins, C. C. (2001). Organizational Research: Determining the Appropriate Sample Size in Survey Research. Information Technology, Learning and Performance Journal, 19(1), 43-50.

Chae, D. R., Wattage, P., \& Pascoe, S. (2012). Recreational benefits from a marine protected area: A travel cost analysis of Lundy. Tourism Management, 33(4), 971-977. doi:https://doi.org/10.1016/j.tourman.2011.10.008

Clough, P. (2013). The value of ecosystem services for recreation. In J. R. Dymond (Ed.), Ecosystem services in New Zealand - conditions and trends (pp. 330-342). Lincoln, New Zealand: Manaaki Whenua Press.

Díaz, M. R., \& Espino-Rodríguez, T. F. (2016). Determining the sustainability factors and performance of a tourism destination from the stakeholders' perspective. Sustainability, 8, 951-968. doi:https://doi.org/10.3390/su8090951

Dixon, J. A., \& Sherman, P. B. (1990). Economics of protected areas: a new look at benefits and costs (1 st). Washington, D.C: Island Press. doi:https://doi.org/19911896498

Farrow, R. S., Goldburg, C. B., \& Small, M. J. (2000). Economic valuation of the environment: A special issue. Environmental Science and Technology, 34(8), 1381-1383. doi:https://doi.org/10.1021/es000944o

Ferland, N. (2011). Tourism in Indonesia. In N. Ferland (Ed.), Measuring Employment in the Tourism Industries beyond a Tourism Satellite Account: A Case Study of Indonesia (pp. 21-28). Jakarta: International Labour Organization.

Fleming, C. M., \& Cook, A. (2008). The recreational value of Lake McKenzie, Fraser Island: An application of the travel cost method. Tourism Management, 29(6), 1197-1205. doi:https://doi.org/10.1016/j.tourman.2008.02.022

Gössling, S. (1999). Ecotourism: A means to safeguard biodiversity and ecosystem functions? Ecological Economics, 29(2), 303-320. doi:https://doi.org/10.1016/S0921-8009(99)00012-9

Grafton, R., Adamowicz, W., Dupont, D., Nelson, H., Hill, R., \& Renzetti, S. (2004). The Economics of the enviroment and natural resourses. (R. Q. Grafton, Ed.). Australia: Blackwell Publishing Inc.

Gujarati, D. N. (2004). Basic Econometrics. United States: The McGraw-Hill Companies.

Hanauer, M. M., \& Reid, J. (2017). Valuing urban open space using the travel-cost method and the implications of measurement error. Journal of Environmental Management, 198, 50-65. doi:https://doi.org/10.1016/j.jenvman.2017.05.005

Irshad, H. (2010). Rural Tourism: An overview. Canada: Government of Alberta, Agriculture \& Rural Development.

Klempener, W. D. (1996). Forest Resources Economics and Finance. Florida, United State: Mc GrawHill. Inc.

Limaei, S. M., Ghesmati, H., Rashidi, R., \& Yamini, N. (2014). Economic evaluation of natural forest park using the travel cost method (case study; Masouleh forest park, north of Iran). Journal of Forest Science, 60(6), 2014-2254. Retrieved from http://www.agriculturejournals.cz/publicFiles/125766.pdf

Martín, J. M. M., Fernández, J. A. S., Martín, J. A. R., \& de Dios Jiménez Aguilera, J. (2017). Assessment of the tourism's potential as a sustainable development instrument in terms of annual stability: Application to Spanish rural destinations in process of consolidation. 
Sustainability, 9, 1692-1712.doi:https://doi.org/10.3390/su9101692

Milon, J. W. (1988). Travel Cost Methods for Estimating the Recreational Benefits of Artificial Marine Habitat. Southern Journal of Agricultural Economics, 20(1), 87-101.

Nillesen, E., Wesseler, J., \& Cook, A. (2005). Estimating the recreational-use value for hiking in Bellenden Ker National Park, Australia. Environmental Management, 36(2), 311-316. doi:https://doi.org/10.1007/s00267-003-0219-7

Ortacesme, V., Özkan, B., \& Karaguzel, O. (2002). An Estimation of the Recreational Use Value of Kursunlu Waterfall Nature Park by the Individual Travel Cost Method *. Turk J Agric, 26, 5762.

Pearce, D. W., \& Turner, R. K. (1991). Economics of Natural Resources and the Environment. American Journal of Agricultural Economics, 73(1), 211-22. doi:https://doi.org/10.2307/1242904

Pirikiya, M., Amirnejad, H., Oladi, J., \& Solout, K. A. (2016). Determining the recreational value of forest park by travel cost method and defining its effective factors. Journal of Forest Science, 62(9), 399-406. doi:https://doi.org/10.17221/12/2016-JFS

Premono, B. T., \& Kunarso, A. (2010). Valuasi Ekonomi Taman Wisata Alam Punti Kayu Palembang. Jurnal Penelitian Hutan Dan Konservasi Alam, 7(1), 13-23.

Rachmansyah, Y., \& Maryono, J. (2004). Pentingnya Valuasi Ekonomi Dalam Pengelolaan Kawasan Konservasi yang Lestari. Jurnal Prestasi, 6(2), 1-17.

Salem, M. E., \& Mercer, D. E. (2012). The economic value of mangroves: A meta-analysis. Sustainability, 4, 359-383. doi:https://doi.org/10.3390/su4030359

Shrestha, R. K., \& Loomis, J. B. (2003). Meta-analytic benefit transfer of outdoor recreation economic values: Testing out-of-sample convergent validity. Environmental and Resource Economics, 25(1), 79-100. doi:https://doi.org/10.1023/A:1023658501572

Shrestha, R. K., Stein, T. V., \& Clark, J. (2007). Valuing nature-based recreation in public natural areas of the Apalachicola River region, Florida. Journal of Environmental Management, 85(4), 977985. doi:https://doi.org/10.1016/j.jenvman.2006.11.014

Sohngen, B., Lichtkoppler, F., \& Bielen, M. (1999). The Value of Day Trips to Lake Erie Beaches. In Ohio Sea Grant College Program (pp. 1-30). Ohio State University.

Sohrabi Saraj, B., Yachkaschi, A., Oladi, J., Fard Teimouri, S., \& Latifi, H. (2009). The recreational valuation of a natural forest park using travel cost method in Iran. IForest, 2(2), 85-92. doi: https://doi.org/10.3832/ifor0497-002

Suhel, \& Bashir, A. (2018). The role of tourism toward economic growth in the local economy. Economic Journal of Emerging Markets, 10(1), 32-39. doi:https://doi.org/10.20885/ejem.vol10.iss1.art4

Tietenberg, T., \& Lewis, L. (2012). Environmental and Natural Resources Economics. (T. H. Tietenberg, Ed.) (9th ed.). New York: Pearson Education, Inc.

Tourism Ministry. (2016). Laporan Akuntabilitas Kinerja Kementerian Pariwisata Tahun 2016. Laporan Kinerja Pariwisata. Jakarta. Retrieved from http://www.kemenpar.go.id/asp/detil.asp?c=16\&id=3101

Twerefou, D. K., \& Ababio, D. K. A. (2012). An economic valuation of the Kakum National Park: An individual travel cost approach. African Journal of Environmental Science and Technology, 6(4), 199-207. doi:https://doi.org/10.5897/AJEST11.159

Zaei, M. E., \& Zaei, M. E. (2013). The Impacts of Tourism Industry on Host Community. European Journal of Tourism Hospitality and Research, 1(2), 12-21. 